\title{
17. ESTIMATED FLUID PRESSURES OF THE BARBADOS ACCRETIONARY PRISM AND ADJACENT SEDIMENTS ${ }^{1}$
}

\author{
J. Casey Moore ${ }^{2}$ and H. Tobin ${ }^{3}$
}

\begin{abstract}
Sediment void ratio of the Barbados accretionary prism and adjacent deposits varies with effective stress and is a basis for estimating long-term variations in fluid pressure. Consolidation tests show that void ratio decreases at differing linear rates with the log of increasing effective stress in carbonate- and clay-rich lithologies from the oceanic reference Site 672 of the northern Barbados Ridge. Using these relationships, we estimate vertical effective stress and fluid pressure (overburden stress minus vertical effective stress) from sites with continuous physical property profiles. The compressive state of stress in the accretionary prism requires correction of effective stress values inferred directly from consolidation tests. We utilize physical property data from both in situ logging-while-drilling (LWD) measurements and measurements on individual core samples. Good correlation between LWD and core sample physical properties indicates the latter are reliable and argues for minimal rebound from in situ conditions.

Estimated fluid pressures are near lithostatic in the décollement zone and proto-décollement zone. Zones of high fluid pressure generally correlate with zones of mud- and mineral-filled veins, suggesting the latter are hydrofractures. Thrust faults tend to occur in intervals of high fluid pressure. Fluid pressures tend to be highest in clay-rich zones. This last correlation could be a result of misrecognition of bound water as porosity, but use of the same techniques to calibrate the consolidation tests as well as to determine the porosity of the samples accounts for this ambiguity. Concentration of deformation in the clay-rich zones may be because of their low coefficient of friction in addition to their high fluid pressure.
\end{abstract}

\section{INTRODUCTION}

Fluid pressure influences structural processes by controlling the effective stress within and near fault surfaces (Hubbert and Rubey, 1959) as well as within deforming accretionary wedges (Davis et al., 1983). fluid-pressure gradients drive fluid flow, and fluid flow is very important in geochemical cycling at convergent margins (Han and Suess, 1989). Diagenetic/metamorphic, and biological features are affected by fluid flow in accretionary prisms (Moore and Vrolijk, 1992) and many other geologic environments. Evaluation of the above phenomena requires information on fluid pressure.

fluid-pressure data are acquired from industry wells by direct measurements using drill stem tests, packer tests, and deployment of repeat formation testers. Indirect measurements of fluid pressures from mud weight, log properties, and drilling data (Fertl, 1976) are commonly utilized because they produce continuous estimates of fluid pressure. These fluid-pressure measurements require empirical correlations and calibration by fewer direct pressure measurements. Fluid pressures have been inferred from mud weight, and logs from industry wells that penetrate uplifted accretionary prism sequences (von Huene and Lee, 1982; Sherwood, 1987; Moore and Vrolijk, 1992), but no such curves are available for Ocean Drilling Program (ODP) holes.

Direct measurements of fluid pressures are difficult in accretionary prisms because of the unstable nature of the boreholes and the operation complexities of working from a moving platform in deep water. Packers have only been successfully utilized in a few cased holes (Fisher and Zwart, Chapter 15, this volume). Point estimates of fluid pressure in the Barbados area have been made from individual con-

${ }^{1}$ Shipley, T.H., Ogawa, Y., Blum, P., and Bahr, J.M. (Eds.), 1997. Proc. ODP, Sci. Results. 156: College Station. TX (Ocean Drilling Program)

${ }^{2}$ Earth Sciences, University of California, Santa Cruz, Santa Cruz, CA 95064, U.S.A. casey@earthsci.ucsc.edu

${ }^{3}$ Department of Geophysics, Stanford University, Stanford, CA 94305-2215, U.S.A. solidation tests (Taylor and Leonard, 1990). However, no continuous estimates of fluid pressure are available from physical properties. Here we use sediment void ratio and consolidation characteristics to estimate fluid pressures from Deep Sea Drilling Project (DSDP)/ ODP Sites 541, 676, and 948, penetrating the northern Barbados accretionary prism, and Site 672 in the incoming sedimentary sequence (Fig. 1).

\section{NATURE OF LOG AND PHYSICAL PROPERTY DATA}

Density data from logging-while-drilling (LWD) and from core measurements are of high quality and correlate well. Density data determined from LWD results, and individual density measurements determined from core samples (Mascle, Moore, et al., 1988; Biju-Duval, Moore, et al., 1984), are the basis for calculation of void ratio. In each case, the in situ determination of the LWD density data closely represents true conditions in the sedimentary sequence, because it was measured minutes after the hole was drilled. The good correspondence between the LWD and core-sample data supports the validity of the latter measurements (Fig. 2). The core data generally follow the LWD density curve, but average about $1 \%$ less dense, which is probably a result of sample decompression from in situ conditions. In comparison, an extremely variable and systematically low wireline density log at Site 948 indicates the latter technology is unsuitable for this environment. The LWD system minimizes problems resulting from hole erosion and intermittent density sensor contact. In contrast, wireline logging operations reentered a previously drilled hole of variable diameter that apparently caused the poor quality log (Shipboard Scientific Party, 1995b). Mud cakes are not an issue in ODP $\log$ data quality because of the absence of a recirculating mud system.

The LWD data provide density measurements at a higher frequency than core data. The frequency of measurement of the core physical property data is about $1.5 \mathrm{~m}$ as opposed to $0.15 \mathrm{~m}$ for the LWD data. Therefore, one aberrant core value can have a large influence. To minimize the impact of unusual lithologies, localized cementation, or 


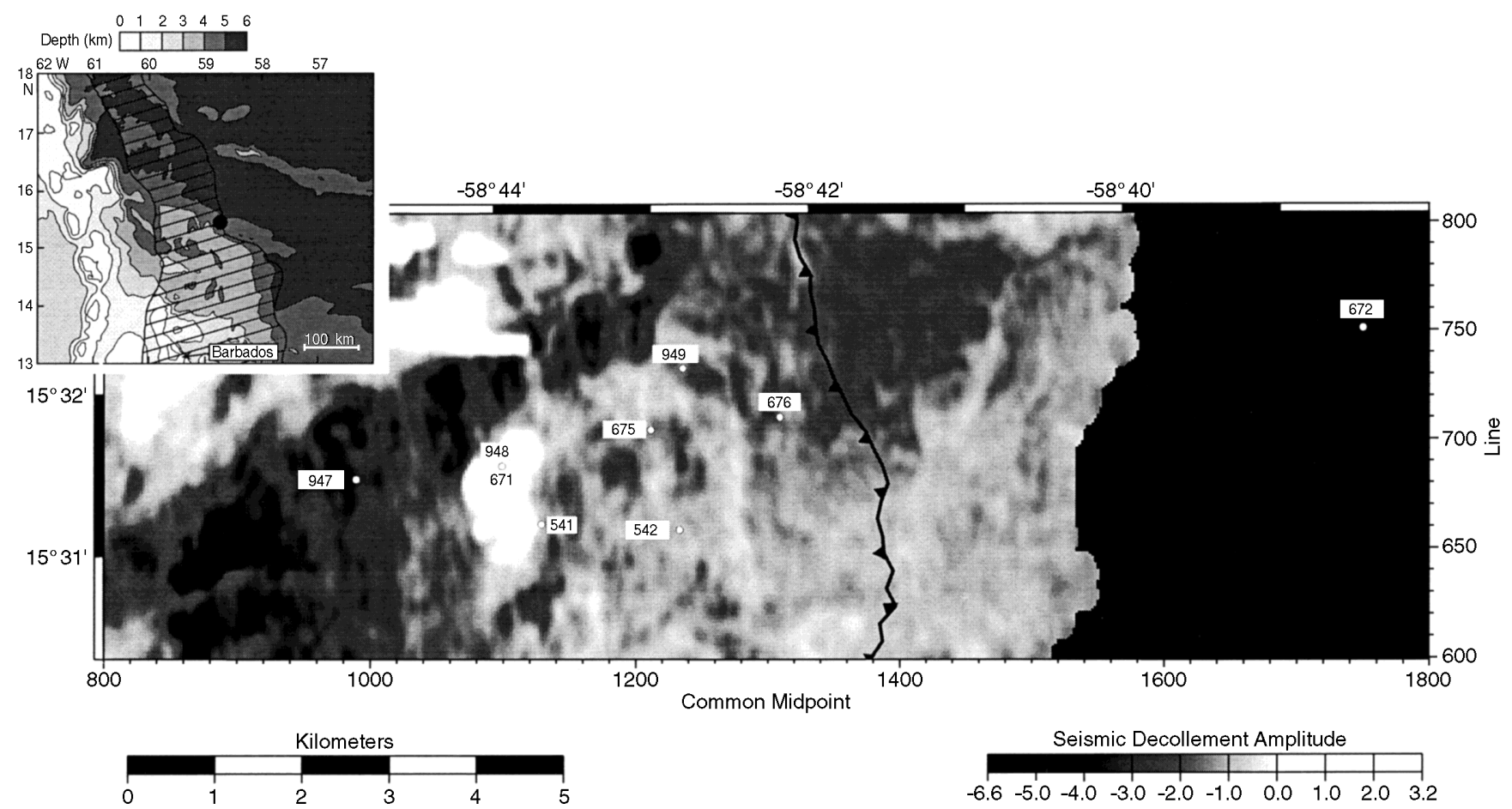

Figure 1. Location map. Sites are located on gray scale map of peak reflection amplitude of the décollement zone (Shipley et al., Chapter 23, this volume).

measurement errors at Sites 672, 676, and 541, we averaged pore pressure curves over a moving window of three samples, usually representing about $5 \mathrm{~m}$ of section.

The good correlation of the LWD density data and density data from core samples suggests consideration of both together as a common data set. Grain density information from cores allows reliable calculation of porosity from the LWD density data by the following relationship (Serra, 1986, p. 381):

$$
\begin{gathered}
\text { Porosity }=(\text { Grain Density }- \text { Wet Bulk Density }) / \\
\text { (Grain Density }- \text { Fluid Density }) .
\end{gathered}
$$

Void ratio is then determined by the following relationship (Blum, 1994):

$$
\text { Void Ratio = Porosity } /(1-\text { Porosity })
$$

Determination of void ratio from core data follows standard shipboard techniques (Blum, 1994).

Two sources of error in void ratio determinations are notable. First, there is a small systematic error in shipboard technique " $B$ " (for details see Blum, 1994) for determination of bulk density. This error results in void ratios that are anomalously high and densities that are anomalously low (Shipboard Scientific Party, 1995a). Because bulk density measurements were determined using technique "B" on previous DSDP and ODP cruises in this area, we continued to use this method on Leg 156 so results can be compared between legs. Second, heating during water content determinations in smectitic clays may remove some of the interlayer water (Brown and Ransom, 1996), resulting in anomalously high estimates of true void ratio. The current measurements may more accurately describe the total water content, not the true void ratio. However, because the void ratios of the consolidation test samples also were determined by "shipboard" techniques, systematic errors associated with the technique or with smectite concentration are the same as in the core samples. Alternatively, the void ratios of the cores samples and the consolidation tests could be corrected for smectite content. However, the absence of knowledge of the hydration state of smectite in the subsurface (K. Brown, pers. comm., 1996) and the lack of knowledge of smectite content in each sample precludes this approach.

\section{ELASTIC REBOUND AND SECONDARY CONSOLIDATION}

Grouping of LWD and core data together requires consideration of effects of elastic rebound and secondary consolidation. At colocated Sites 671 and 948, core sample (unloaded) densities are one percent less than the in situ LWD densities, suggesting minimal rebound (Fig. 2). Tobin and Moore (Chapter 9, this volume) determined a volumetric change of a maximum of one percent when compressing samples from surface to in situ conditions, consistent with the field observations. The mean rebound from the consolidation tests used here ranged from $10 \%$ to $17 \%$ in volume, over a typical range of void ratios (0.9-1.5). However, these tests reached effective stresses substantially higher than in situ conditions. The higher rebound in the higher stress tests may be because of the lack of secondary consolidation that would release elastic strain. Because the elastic rebound from field conditions is small, we have made no accommodation for rebound in comparison of the core and LWD data. Over long time periods, secondary consolidation decreases void ratio at constant effective stress (Mitchell, 1976, p. 273-275). Therefore short-term tests tend to overestimate the effective stress when compared to sediments with void ratios reduced because of consolidation over geologic time. We have made no correction for this effect, which would tend to underestimate fluid pressures.

\section{CALCULATION OF FLUID PRESSURES}

Sediment void ratio varies with stress history. During consolidation, total stress is supported partly by the mineral framework (effective stress) and partly by the interstitial fluid (neutral stress or fluid 


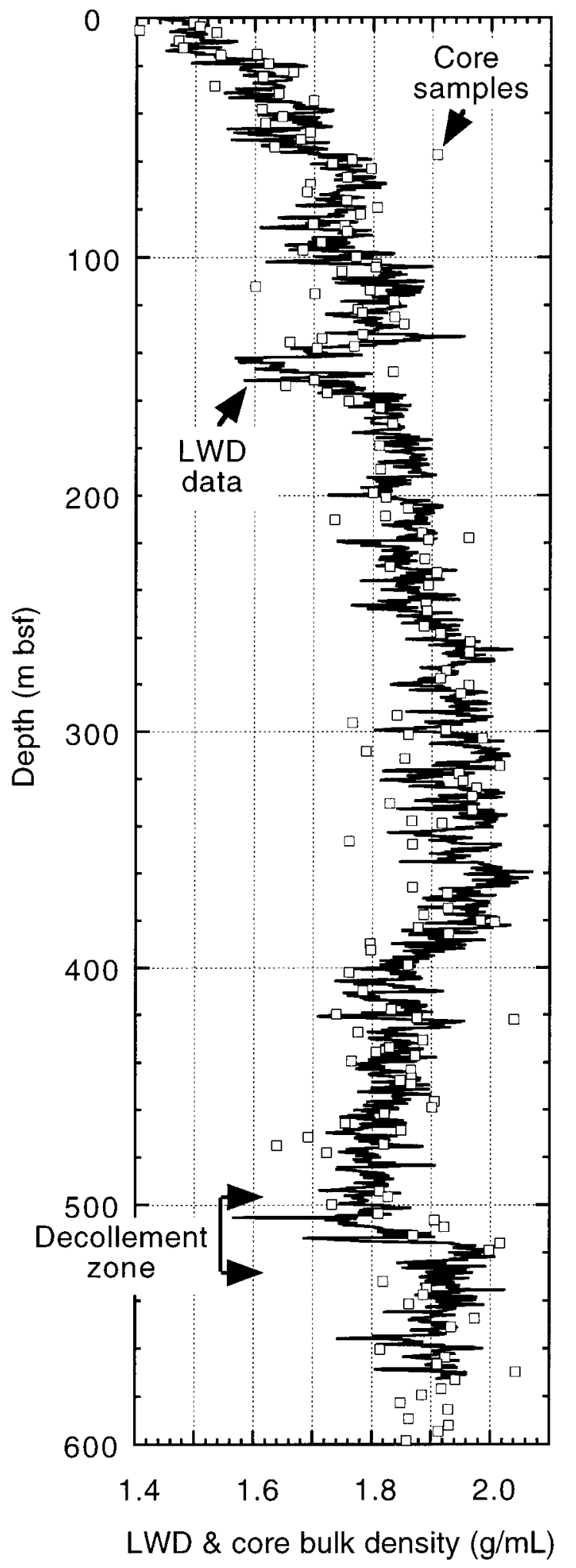

Figure 2. LWD density from Site 948 compared to core sample density data from Site 671 at the same location (Shipboard Scientific Party, 1988a).

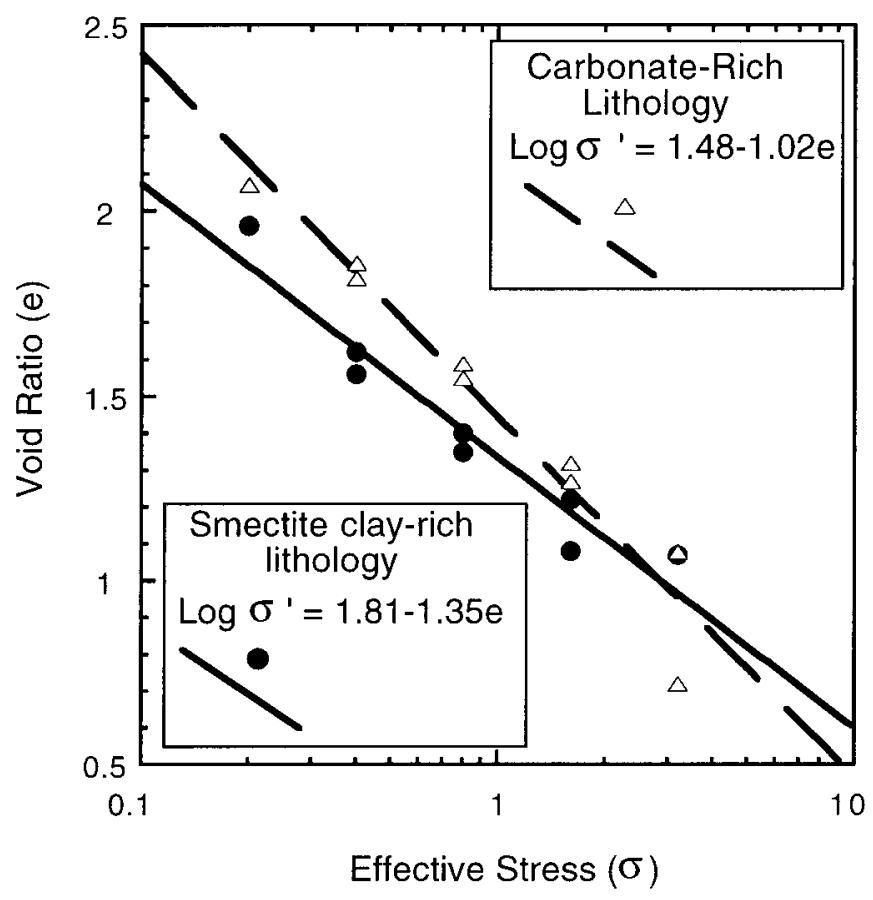

Figure 3. Void ratio vs. effective stress curves for Site 672 (from Taylor and Leonard, 1990). Effective stress values are the axial load or the maximum principal stress $\left(\sigma_{1}\right)$ in the consolidation test. Tests on carbonate-rich sediment are from samples at 7.7 and 55 mbsf. Tests on clay-rich sediment are from 112 and 166 mbsf.

pressure; Terzaghi and Peck, 1948). Irreversible plastic deformation with void ratio reduction dominates consolidation of sediment, providing the fluid can escape. If the fluid remains trapped or is resupplied, consolidation is retarded, and the fluid pressure rises proportionally to support the load stress. Therefore, sediment void ratio directly indicates the past effective stress and fluid pressure, provided the total stress is known.

Various approaches can be used to estimate effective stress from consolidation characteristics. During consolidation, sediments initially deform elastically, followed by primary or plastic consolidation. Commonly, the transition from elastic to plastic behavior is used to estimate the past maximum effective stress for an individual sample (Casagrande, 1936). During primary or plastic consolidation, void ratio and log effective stress show a negative linear relationship (Terzaghi and Peck, 1948). With this relationship for a particular sediment type, the maximum past effective stress can be estimated from known void ratios (Fig. 3). Estimates by the Casagrande technique or from the void ratio-effective stress curve, as done here, both provide a long-term measure of stress and fluid-pressure history, not an instantaneous view.

To estimate effective stress and fluid pressure, we utilize the relationship between void ratio and effective stress for the two dominant sediment types of the accretionary prism in the Leg 156 area. Consolidation curves from Site 672 define our reference void ratio to effective stress relationship. Site 672 is the best reference locality because it is located 6-km seaward of the deformation front and is only locally deformed in the proto-décollement zone by the encroaching prism (Mascle, Moore, et al., 1988). Because sediment compressibility varies with lithology, we have compiled separate reference curves for 


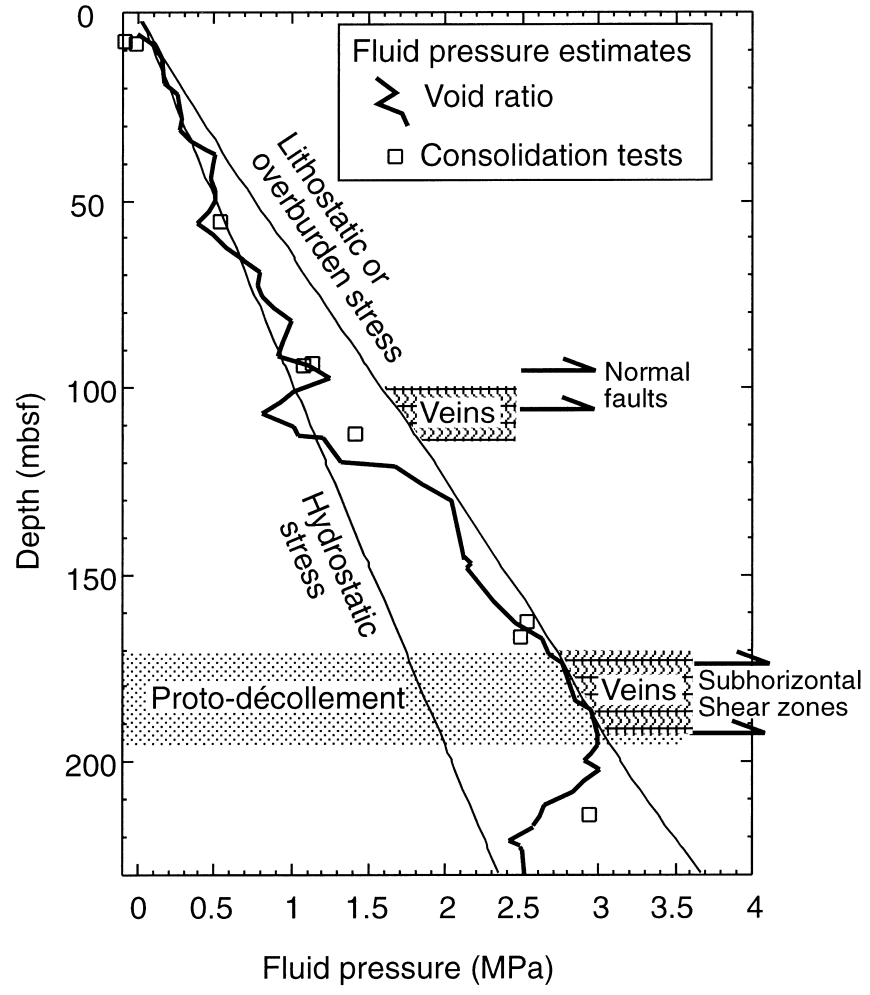

Figure 4. Estimated fluid pressure from Site 672 with spot values from consolidation tests. Fluid-pressure curve is smoothed over a 3-pt. moving window of about $5 \mathrm{~m}$ of section.

carbonate-rich and smectitic clay-rich sediments using only the consolidation tests with linear primary consolidation curves (Taylor and Leonard, 1990; Fig. 3). We split the consolidation data into carbonate-rich and clay-rich lithologies as indicated by compositions determined by X-ray mineralogy (Shipboard Scientific Party, 1988b; Schoonmaker Tribble, 1990). A sharp increase in clay and smectite content below $100 \mathrm{~m}$ depth at Site 672, as shown in the X-ray data, is the basis for our separation. The two consolidation curves do not account for internal variations in clay content within the two units, but are more lithologically sensitive than summing data from all consolidation tests at Site 672 (Moore et al., 1995).

\section{Site 672: Reference Locality on Incoming Oceanic Plate}

Estimating the effective stress and fluid pressure at Site 672 (Fig. 4) follows directly from the void ratio-effective stress relationship, because the site lies where it has a dominantly "basinal" state of stress (Fig. 5A). The relationship shown on Figure 3 allows each void ratio measurement at Site 672 to be interpreted in terms of vertical effective stress $\left(\sigma_{v}^{\prime}\right.$ or $\left.\sigma_{1}^{\prime}\right)$, after considering whether it lies in a carbonateor clay-rich lithologic unit. The overburden equals $\rho_{\mathrm{wb}} \mathrm{gz}$, where $\rho_{\mathrm{wb}}$ is wet bulk density from cores, $g$ is the acceleration of gravity, and $z$ is the depth. Fluid pressure (p) in Figure 4 is equivalent to the overburden or total vertical stress less the vertical effective stress determined from the consolidation test or

$$
\mathrm{p}=\rho_{\mathrm{wb}} \mathrm{gz}-\sigma_{\mathrm{v}}^{\prime}
$$

Fluid pressure estimates made here from the void ratio-effective stress relationship agree well with those determined from individual consolidation tests using the Casagrande technique (Fig. 4). The consolidation tests show pressures slightly less than hydrostatic within $10 \mathrm{~m}$ of the seafloor, indicating overconsolidation of the most surficial deposits, a condition commonly observed at or near the surface (Taylor and Leonard, 1990). Overall fluid pressures determined from consolidation tests are near hydrostatic to about $100 \mathrm{~m}$ below seafloor (mbsf) and increase to much higher values below $125 \mathrm{mbsf}$.

\section{Sites 676, 541, and 948 Arcward Across the Accretionary Prism}

The state of stress in the accretionary prism contrasts with that in the adjacent sedimentary basin, requiring a differing treatment of consolidation results to estimate fluid pressure. The load stress or maximum principal effective stress applied during the consolidation test is directly comparable to vertical effective stress at Site 672 (Fig. 5A). In the frontal part of accretionary prisms, analysis of thrust fault geometries and limited measurements indicate a shallowly dipping, approximately horizontal, maximum principal stress (e.g., Lallemant et al., 1993; Moran et al., 1993; Fig. 5A). Sediment entering the prism is transformed from the basinal state of stress by an increasing lateral stress so that the horizontal stress becomes the maximum principal stress. Sediment underthrust beneath the décollement is not thrust faulted and probably more closely approximates the basinal state of stress.

Estimating the fluid pressure at Sites 676, 541, and 948 with the approach used at Site 672 yields unreasonable results because we do not account for the differing state of stress in the prism (Fig. 5A). For example, in Figure 6, we have determined the apparent effective stress $\left(\sigma_{\mathrm{a}}^{\prime}\right)$ from void ratio (Fig. 3) and subtracted it from the total overburden stress $\left(\rho_{\mathrm{wb}} \mathrm{gz}\right)$, to yield apparent fluid pressures $\left(\mathrm{p}_{\mathrm{a}}\right)$ for Sites 676,541 , and 948 , or

$$
p_{a}=\rho_{w b} g z-\sigma_{a}^{\prime} .
$$

The apparent fluid pressures are progressively lower away from the deformation front east across the prism from Sites 676 to 541 to 948 , getting well below hydrostatic, a geologically unreasonable result. The decrease in apparent fluid pressure across the prism probably reflects the effect of the increasing horizontal stress.

A proper transformation of the void ratio of prism sediments to vertical effective stress requires information on the state of stress at the sample localities. The effective stress in Figure 3 is the maximum principal stress of the consolidation test, approximating the vertical stress conditions at Site 672 and most probably the horizontal stress in the prism (Fig. 5A). Although information exists on the orientation of stresses in modern accretionary prisms (Lallemant et al., 1993), few direct measurements of relative stress magnitude are available (Moran et al., 1993). To estimate the fluid pressure in the accretionary prism, we had to correct the effective stresses determined from the consolidation tests to values approximating the vertical effective stress.

\section{Corrections: Background and Assumptions}

Estimation of the fluid pressure in the accretionary prism requires correction of the effective stress data for the lateral compressive stresses in the prism. The sediment below the décollement zone may revert to state of stress with the maximum principal stress vertical (Moran et al., 1993; Fig. 5A). Because we do not know the interval over which this stress transition takes place, we have not attempted to correct the fluid pressures back to this state. We attempted both experimentally and empirically parameterized corrections within the accretionary prism. Both corrections depend on the following assumptions.

1. Void ratios determined from density logs correspond to mean normal effective stresses. Figure 3 shows the relationship between the maximum principal stress and void ratio for uniaxial 


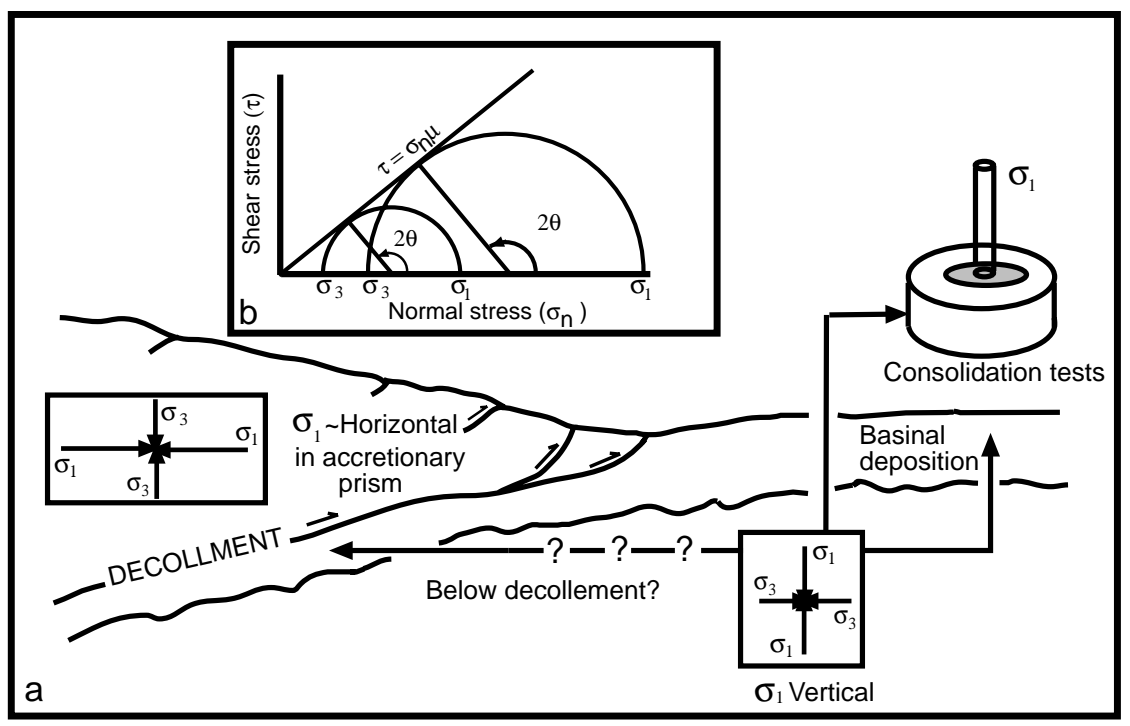

Figure 5. A. Typical stress orientations in sedimentary basins, consolidation tests, and accretionary prisms, in part after Lallemant et al. (1993).

B. Mohr diagram graphically shows the constancy of $\sigma_{1}^{\prime} / \sigma_{3}^{\prime}$ for different Mohr circles at failure, given a constant slope of the Mohr failure envelope.

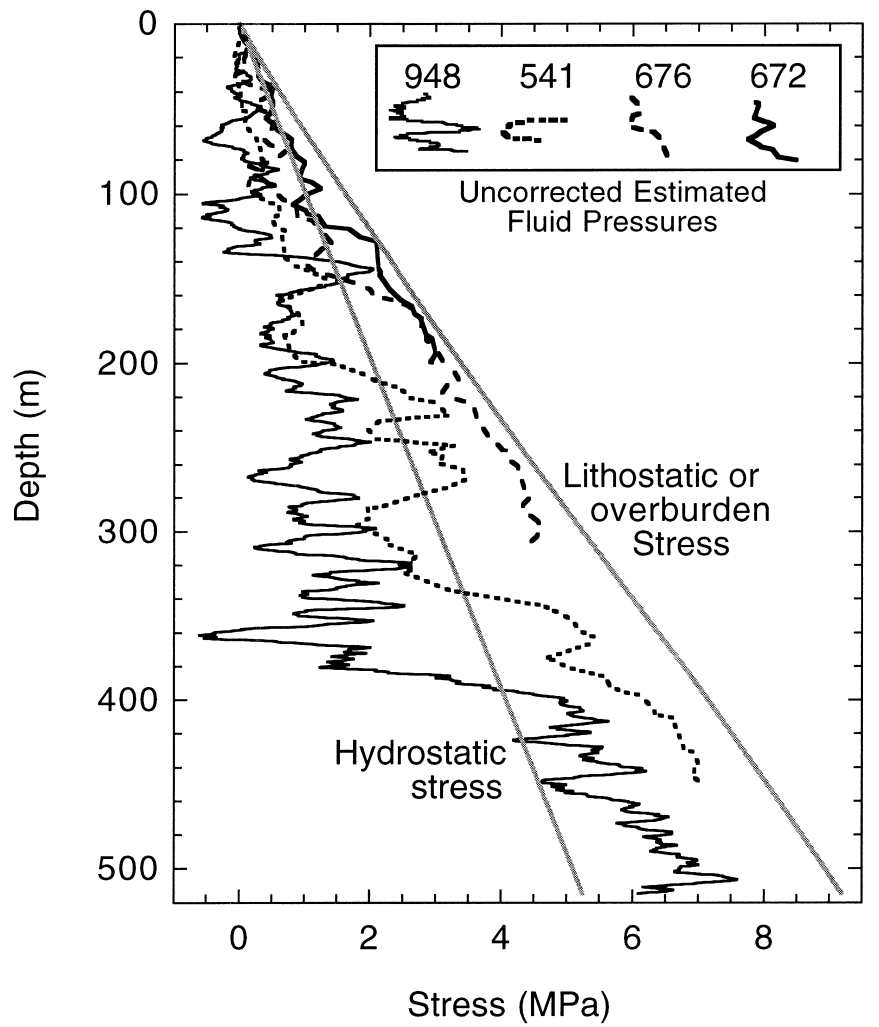

Figure 6. Estimated fluid pressures (uncorrected) from Sites 672, 676, 541, and 948. Note decreasing apparent pressures from east to west (Sites 672676-541-948). The apparent pressure curves are smoothed over moving window of about $5 \mathrm{~m}$ of section.

strain; the experimental and empirical corrections use different parameters to determine the mean normal effective stress.

2. The prism is at failure from the surface, where the fluid pressure is hydrostatic, down through the décollement. Several lines of evidence support this assumption. Numerous thrust faults that cut through the prism and offset the surface indicate a state of failure (Shipley, Ogawa, Blum, et al., 1995). More- over, Coulomb wedge theory requires that prisms are at failure and accordingly relates the shape and fluid pressure of accretionary prisms both globally (Davis et al., 1983) and at Barbados (Davis, 1984). The success of Coulomb wedge theory in explaining the geometry and fluid-pressure observations in growing accretionary prisms is consistent with the assumption that the Barbados prism is essentially at failure.

3. At a given location the prism sediments have a uniform coefficient of friction. Triaxial tests by Moran and Christian (1990) fit both clay-rich and carbonate rich sediments from the northern Barbados prism with the same failure envelope or coefficient of friction.

4. The cohesion is negligible. Triaxial tests by Moran and Christian (1990) have a cohesion intercept that is very low $(9 \mathrm{kPa})$.

5. The maximum principal stress is horizontal, the minimum principal stress is vertical in the prism (Lallemant et al., 1993), and the stress is uniaxial $\left(\sigma_{2}=\sigma_{3}\right.$ and $\left.\sigma_{2}^{\prime}=\sigma_{3}^{\prime}\right)$.

Both corrections require determination of a vertical effective stress that is less than the stress that is directly inferred from the consolidation test (Fig. 3). In each case, the corrected effective stress is subtracted from the vertical effective stress to determine the fluid pressure as above in Equation 3.

Using the same percentage reduction in effective stress over the entire borehole requires the constancy of the ratios of maximum and minimum principal effective stresses. The constancy of the ratios of the maximum and minimum principal stresses in an individual borehole holds if the prism is at failure, the materials in the borehole have a uniform coefficient of friction, and the cohesion is zero. Given that the above three conditions hold, the constant ratio of principal effective stresses can be shown by combining the equations for the Coulomb failure envelope for a cohesionless material

$$
\tau=\sigma_{n}^{\prime} \mu
$$

with the equations for the shear

$$
\tau=\left[\left(\sigma_{1}^{\prime}-\sigma_{3}^{\prime}\right) / 2\right] \sin 2 \theta,
$$

and normal effective stresses

$$
\sigma_{\mathrm{n}}^{\prime}=\left(\sigma_{1}^{\prime}+\sigma_{3}^{\prime}\right) / 2+\left[\left(\sigma_{1}^{\prime}-\sigma_{3}^{\prime}\right) / 2\right] \cos 2 \theta
$$


of the Mohr circle, where $\tau$ is shear stress $\sigma_{n}^{\prime}$ is normal effective stress, $\mu$ is the coefficient of friction, $\sigma^{\prime}{ }_{1}$ is maximum principal effective stress, $\sigma_{3}^{\prime}$ is minimum principal effective stress, and $\theta$ is the angle between the maximum principal stress and the normal to the failure plane measured in a counterclockwise direction (Twiss and Moores, 1992). The substitution Equations 6 and 7 into Equation 5 specifies the relationship between the principal stresses along the failure envelope:

$$
\begin{gathered}
{\left[\left(\sigma_{1}^{\prime}-\sigma_{3}^{\prime}\right) / 2\right] \sin 2 \theta=} \\
\left\{\left[\left(\sigma_{1}^{\prime}+\sigma_{3}^{\prime}\right) / 2+\left(\sigma_{1}^{\prime}-\sigma_{3}^{\prime}\right) / 2\right] \cos 2 \theta\right\} \mu .
\end{gathered}
$$

By expanding this relationship, combining terms, and factoring it can be shown that (9)

$\sigma_{3}^{\prime} / \sigma_{1}^{\prime}=(\sin 2 \theta-\mu-\mu \cos 2 \theta) /(\sin 2 \theta+\mu-\mu \cos 2 \theta)=R$.

The ratio of the principal stresses is therefore a constant (R) along the failure envelope, because the coefficient of friction is constant and the angular relationship between the failure surface and the principal stresses at failure is constant (Fig. 5B; Twiss and Moores, 1992).

\section{Experimentally Parameterized Correction}

An approach to correction of the void ratio-effective stress relationships for Site 948 involves interpretation of the effective stress from Figure 3 as the horizontal maximum principal effective stress in the prism or $\left(\sigma_{1}^{\prime}\right)$. The vertical effective stress can be estimated if we know (1) the ratio of principal stresses in the consolidation test and by inference the prism, and (2) that the minimum and intermediate principal stresses are equal in the prism $\left(\sigma_{2}=\sigma_{3}\right.$ and $\left.\sigma_{2}^{\prime}=\sigma_{3}^{\prime}\right)$, or the state of stress is uniaxial.

Evaluating the relationship between the principal stresses in consolidation tests, and by inference the prism, requires use of experimental results from a study of hemipelagic sediments, as both maximum and minimum principal stresses are not normally measured in consolidation tests. Karig and Hou (1992) consolidated a synthetic hemipelagic clay in an apparatus that recorded the maximum and minimum principal stresses; the minimum principal effective stress was consistently 0.62 of the maximum principal effective stress. Therefore, $\mathrm{R}$ from Equation 9 equals 0.62 . The mean effective stress that controls consolidation $\left(\sigma_{\mathrm{m}}^{\prime}\right)$ is as follows:

$$
\sigma_{\mathrm{m}}^{\prime}=\left(\sigma_{1}^{\prime}+\sigma_{2}^{\prime}+\sigma_{3}^{\prime}\right) / 3
$$

From Equation 9 we know that

$$
\sigma_{3}^{\prime} / \sigma_{1}^{\prime}=\mathrm{R}
$$

and because $\sigma_{2}^{\prime}=\sigma_{3}^{\prime}$, Equation 10 may be restated as:

$$
\sigma_{\mathrm{m}}^{\prime}=\left(\sigma_{1}^{\prime}+2 \mathrm{R} \sigma_{1}^{\prime}\right) / 3
$$

or

$$
\sigma_{\mathrm{m}}^{\prime}=\left(\sigma_{1}^{\prime}+2 \sigma_{3}^{\prime}\right) / 3=\left[(1 / \mathrm{R}+2) \sigma_{3}^{\prime}\right] / 3
$$

Rearrangement of Equation 13 yields:

$$
\sigma_{3}^{\prime}=(3 R / 1+2 R) \sigma_{m}^{\prime}
$$

Because $\sigma_{3}^{\prime}$ is the vertical stress, by substituting into Equation 3, pore pressure is:

$$
\mathrm{p}=\rho_{\mathrm{wb}} \mathrm{gz}-{\sigma^{\prime}}_{3}=\rho_{\mathrm{wb}} \mathrm{gz}-(3 \mathrm{R} / 1+2 \mathrm{R}) \sigma_{\mathrm{m}}^{\prime},
$$

and by substituting Equation 12 for $\sigma_{\mathrm{m}}^{\prime}$,

$$
\mathrm{p}=\rho_{\mathrm{wb}} \mathrm{gz}-(3 \mathrm{R} / 1+2 \mathrm{R})\left({\sigma^{\prime}}_{1}+2 \mathrm{R}{\sigma^{\prime}}_{1}\right) / 3 .
$$

Therefore, pore pressure can be determined at any depth, because $\rho_{\mathrm{wb}}$ is known from cores or logs, $\mathrm{R}$ is known from the experiments by Karig and Hou (1992), and $\sigma_{1}^{\prime}$ is known from the consolidation tests (Fig. 3). Applying this relationship to the data from Site 948 yields the experimentally parameterized fluid-pressure curve in Figure 7. This curve lies below hydrostatic to greater than $350 \mathrm{mbsf}$.

Our "experimental" correction only partially adjusts for the complicated state of stress in the prism. The inadequacy of this correction could be due to many reasons. The intermediate principal stress in the prism may be greater than the minimum principal stress. The ratio of maximum and minimum principal effective stresses determined by Karig and Hou (1992) may not apply to the Barbados sediments. The ratio of principal effective stresses in the prism, at a condition of failure, may be different from those in a consolidation test, which is at yield. Our experimental approach ignores the effect of shear stress on consolidation. Given these ambiguities, we abandoned correcting the effective stresses from an experimental perspective and attempted an empirical correction.

\section{Empirically Parameterized Correction}

Our empirical approach follows common practice in the oil industry, where normal trends in some petrophysical property (e.g., density, resistivity, sonic velocity) are defined, and deviations are interpreted in terms of pore pressure (Fertl, 1976). Typically, these deviations are ground-truthed locally by direct fluid-pressure measurements, whether by packers, drill stem tests, or repeat formation testers. These empirical estimates are useful within a particular area, with new calibrations necessary as drilling progresses to other regions (Hottman et al., 1979). With no industry drilling experience in the northern Barbados Ridge area, we have had to develop our own empirical correction scheme.

The empirical correction generally follows the scheme of the experimental correction, but defines the ratio of principal stresses based on the assumption that fluid pressures are hydrostatic in the upper part of each hole. We assume that the maximum principal effective stress is horizontal in the prism, and the minimum principal effective stress is vertical. Although fluid pressures are generally high in accretionary prisms, they tend to follow hydrostatic gradients near surface (von Huene and Lee, 1983; Sherwood, 1987; Moore and Vrolijk, 1992). Specifically, we note that the fluid pressure in the basinal setting at Site 672 is approximately hydrostatic to about $100 \mathrm{~m}$ depth. As these basinal sediments are incorporated into the prism, fluid pressures should be at least equal to, if not exceeding, the hydrostatic baseline. Therefore, by using a variation of Equation 3, we empirically determine the vertical effective stress or $\left(\sigma_{3}^{\prime}\right)$ as

$$
\sigma_{3}^{\prime}=\rho_{\mathrm{wb}} g z-p_{\mathrm{h}}
$$

where $\mathrm{p}_{\mathrm{h}}$ is the hydrostatic pressure determined from the mean density of seawater at this depth $\left(1.04 \mathrm{~g} / \mathrm{cm}^{3}\right.$; Fisher and Zwart, Chapter 15 , this volume) and expressed as an excess over the pressure on the seafloor. Over the upper hundred meters of each site, this empirically determined $\sigma_{3}^{\prime}$ is divided by the $\sigma^{\prime}{ }_{1}$ determined from the consolidation tests to define a mean empirical R (see Eq. 9). Each site therefore has a unique, empirically determined R. We assume R is constant for a particular borehole. We determine fluid pressure by substituting this unique $\mathrm{R}$, a unique $\rho_{\mathrm{gw}}$ for each depth, and $\sigma^{\prime}{ }_{1}$ determined from the consolidation tests at each depth into Equation 15. 


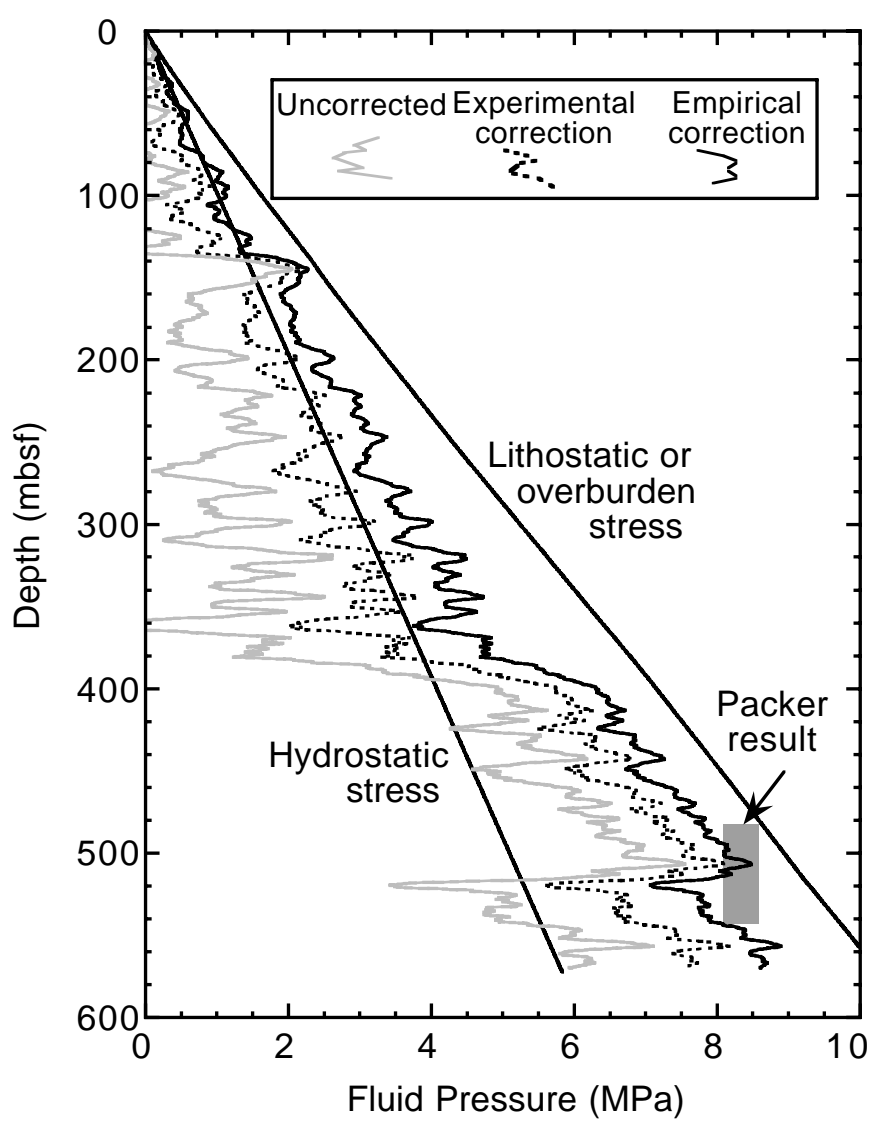

Figure 7. Fluid-pressure curve showing effects of various assumptions of lateral stress in calculation of fluid pressure. Fluid-pressure curves are smoothed by a $5-\mathrm{m}$ moving average so they can be distinguished. Some spikes in data eliminated by this presentation are considered significant; thus preferred pressure curve in Figure 10 is not smoothed. Packer result from Fisher and Zwart (Chapter 15, this volume).

Shifting and fitting the fluid-pressure curve to hydrostatic over the upper $100 \mathrm{~m}$ of each site averages over small-scale variations in this curve. At some sites slight overconsolidation occurs in the initial few meters of the boreholes (Taylor and Leonard, 1990), which in our scheme predicts less than hydrostatic pore pressures. Because our empirical correction utilizes a $100 \mathrm{~m}$ section, any effects of overconsolidation at the surface do not significantly affect the curve fit.

The empirically determined values of $\mathrm{R}$ at Sites 676, 541, and 948 are $0.62,0.42$, and 0.38 . These ratios of vertical to horizontal effective stresses overlap ratios of vertical to horizontal effective stresses measured at shallow depths in the Nankai prism (Moran et al., 1993). These numbers suggest an increase in the ratio of horizontal to vertical effective stress and changing mechanical properties arcward from Site 676 to Site 948.

Overall, we believe that the empirical correction of effective stresses provides the most reasonable estimates of fluid pressure. Our empirical correction is conservative and consistent with the single direct packer measurement of fluid pressure at Site 948 (Fig. 7). The pressure curve from Site 672 lies near hydrostatic, although it has not been yet incorporated in the prism (Fig. 4). Deformation may drive the upper portions of boreholes in the prism above hydrostatic, making our empirical correction conservative. The consistency between our estimated fluid pressures and the packer tests must be evaluated from the perspective that the packer tests are instantaneous measurements and our consolidation-based estimate reflects a long-term pressure history.

\section{INTERPRETATION OF ESTIMATED FLUID PRESSURES}

Even though our fluid-pressure curves are model dependent, they show features that can be directly related to geological phenomena influenced by high fluid pressures. The following interpretations of structures with respect to estimated fluid pressure are presented in the order of increasing structural complexity. Unless otherwise noted, the site reports of DSDP/ODP Initial Reports volumes provide structural data to which the fluid-pressure curves are compared (BijuDuval, Moore, et al., 1984; Mascle, Moore, et al., 1988; Shipley, Ogawa, Blum, et al., 1995).

\section{Structural and Hydrologic Character}

\section{Site 672}

Site 672 shows only minor structural influence of the encroaching accretionary prism that is located $6 \mathrm{~km}$ to the west of the site. Near the proto-décollement, the estimated fluid-pressure curve is at lithostatic pressure over a $25-\mathrm{m}$-thick interval that is also characterized by mud-filled veins in subhorizontal shear zones (Fig. 4). Veins are also observed at about $100 \mathrm{mbsf}$ and are associated with a normal fault. Brown and Behrmann (1990) interpret the shallowly dipping shears as incipient thrusting along the décollement zone. The veins associated with the normal fault occur where the estimated fluid-pressure curve is near hydrostatic. In general, hydrofractures occur with normal faults in hydrostatically pressured sections at shallow depths in sediments, making the occurrence of veins and low estimated fluid pressures reasonable (Behrmann, 1991). The normal faults may have allowed for drainage to the surface, accounting for the low estimated fluid pressures.

The origin of the high fluid pressure in sediment lying between $125-\mathrm{m}$ and $200-\mathrm{m}$ subbottom at Site 672 is problematic. The overlying section accumulated at a rate of about $25 \mathrm{~m} / \mathrm{m}$.y. (Shipboard Scientific Party, 1988b), which is not usually adequate to create or maintain high fluid pressures in the subjacent unit. Moreover, Site 672 has been located many tens of kilometers seaward of the encroaching accretionary prism for much of its history. In part, the very low permeability of this muddy section explains maintenance of high fluid pressure (Brückmann et al., Chapter 7, this volume). Site 672 is located on a high in the oceanic crust that is flanked by thicker sediments (Speed et al., 1984). The greater overburden of flanking sediments relative to the equivalent overpressured section may create a head difference and drive flow towards Site 672. This flow may have allowed long-term maintenance of the high fluid pressure.

\section{Site 676}

Site 676 is at the toe of the accretionary prism near the onset of seismically resolvable thrusting. A shallow fault at about $40 \mathrm{mbsf}$ occurs within a zone of approximately hydrostatic fluid pressures (Fig. 8). A minor increase in fluid pressure just below the fault may result from thrust loading. Otherwise, thrust faults and mud-filled veins all occur in association with near-lithostatic fluid pressures. Estimated pressures in the décollement are at lithostatic.

\section{Site 541}

Site 541 is located $4-\mathrm{km}$ landward of the prism toe and is characterized by well-developed imbricate thrusting. High fluid pressures characterize the décollement zone at Site 541 (Fig. 9). High fluid pressure correlates with a zone of veining, scaly fabric, and stratal disruption from $360 \mathrm{mbsf}$ to the base of the hole at $457 \mathrm{mbsf}$. Elevated fluid pressures also characterize a zone about 70 mbsf above two closely spaced imbricate thrusts in the prism at about $275 \mathrm{mbsf}$. 


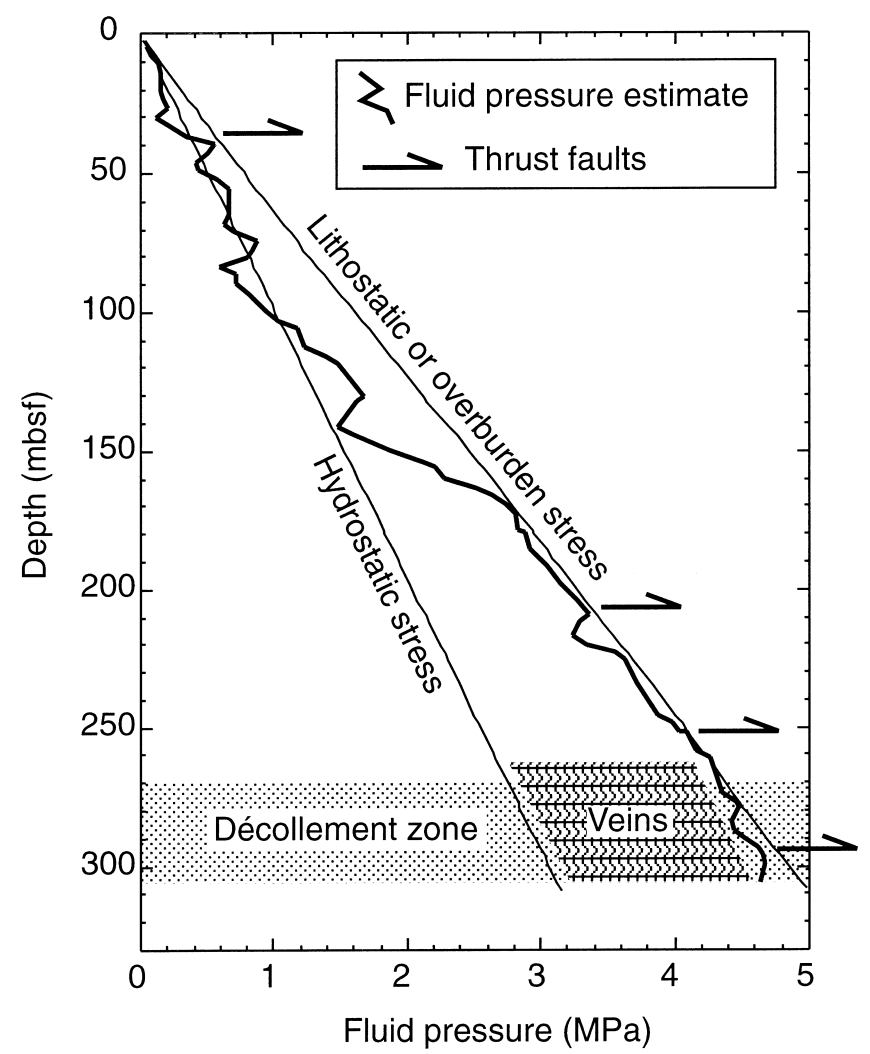

Figure 8. Estimated fluid pressure (corrected) from Site 676. The fluid-pressure curve is smoothed over a 3-pt. moving window of about $5 \mathrm{~m}$ of section.

\section{Site 948}

Sites 671 and 948 are co-located $4.5 \mathrm{~km}$ west of the toe of the accretionary prism. Here zones of estimated overpressures correlate with thrust faults (Fig. 10). At 128-m subbottom at Site 671, a thrust fault displaces the section vertically $175 \mathrm{~m}$. Immediately beneath this fault, the estimated pore-pressure curve rises to greater than $95 \%$ of lithostatic. These overpressures likely develop because of loading of the footwall sediment by the hanging wall of the fault. Similarly at Site 671, several thrust faults are present below $380 \mathrm{mbsf}$, but above the décollement. At $360 \mathrm{mbsf}$, the pore-pressure curve rises sharply from estimated fluid pressures of about $70 \%$ of lithostatic to about $90 \%$ of lithostatic. The section between $380 \mathrm{~m}$ and the décollement zone is exceptionally clay rich and overpressured in its depositional setting on the oceanic plate (Taylor and Leonard, 1990). The concentration of thrusting and thickening of the sedimentary section contributes to the overpressures.

\section{Geochemical Anomalies}

\section{Sites 672 and 948}

Estimated fluid pressure information provides new insights on the relationship between structural features, pore-water geochemistry, and hydrogeology. Anomalies in pore-water geochemistry indicate that major fluid migration is concentrated in the proto-décollement and décollement zones (Gieskes et al., 1990). Our fluid-pressure profiles penetrate these zones at Sites 672 and 948 . At both sites, the geochemical anomalies in these zones are associated with the highest excess fluid pressures (total fluid pressure minus hydrostatic pressure). As the fluid here is chemically exotic (Gieskes et al., 1990), it

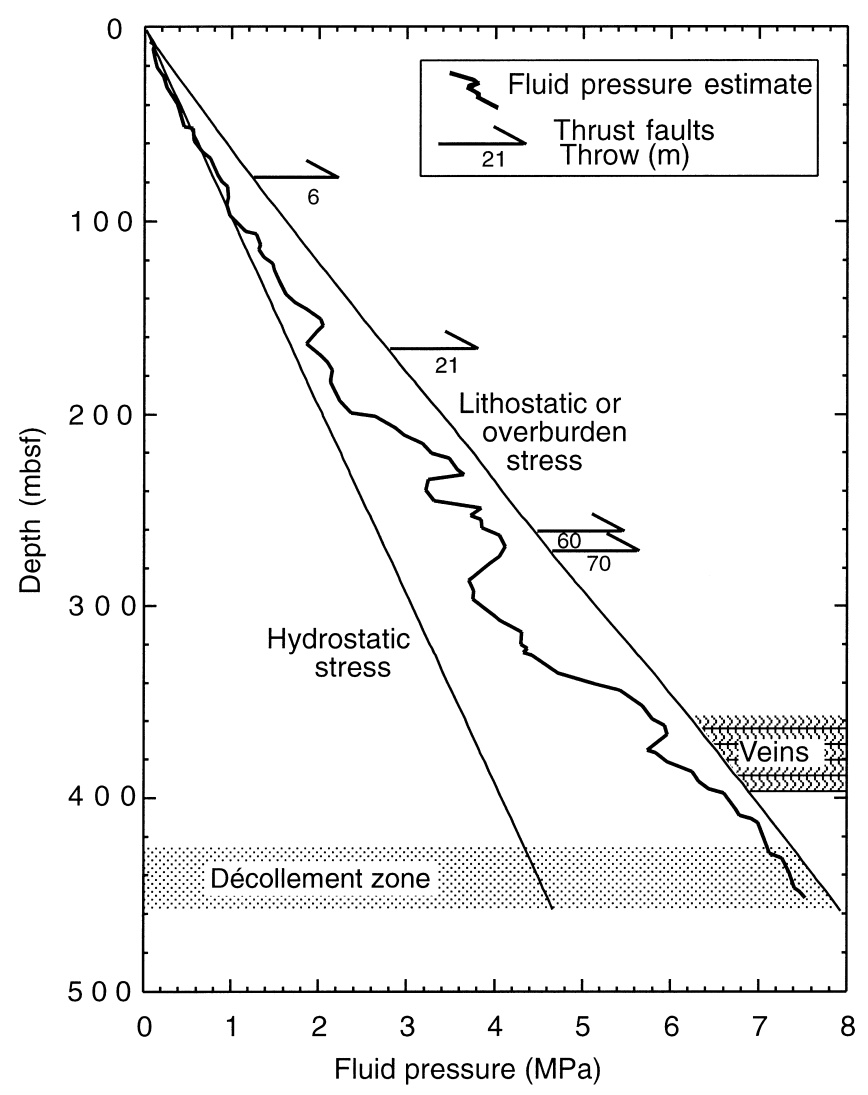

Figure 9. Estimated fluid pressure (corrected) from Site 541. The fluid-pressure curve is smoothed over a 3-pt. moving window of about $5 \mathrm{~m}$ of section.

cannot be derived locally. Therefore, this excess fluid pressure is caused by or maintained by lateral influx of fluid.

\section{DISCUSSION: FLUID PRESSURES AND CLAY CONTENT}

Sections with high fluid pressure are commonly characterized by high clay contents. This would be the expected correlation if we have misidentified structurally bound water as porosity (Brown and Ransom, 1996) and overestimated fluid pressure. We argued above that because the same techniques were used for physical property determinations on the borehole samples and the samples from consolidation tests, any errors caused by measurement of structurally bound water as real water will cancel. Also, high fluid pressures are locally observed in areas of low clay and smectite content (e.g., below the thrust fault at $128 \mathrm{~m}$ at Sites 671/948).

In addition, geological and borehole observations support the presence of high estimated fluid pressures in the clay-rich sections. Mud- and mineral-filled veins in clay-rich sections indicate that the associated sediments reached the hydrofracture threshold (Labaume et al., Chapter 5, this volume). If the prism is in compression, these hydrofractures indicate near-lithostatic fluid pressures.

We do not believe our approach falsely identifies high fluid pressures, but we do not doubt that the clays have special properties that favor overpressuring. The fundamentally low permeability of the smectite-rich clay lithology would assist in maintaining the high fluid pressures (Brückmann, et al., Chapter 7, this volume). Structural imbrication of the low permeability clay-rich sections would favor overpressuring. 


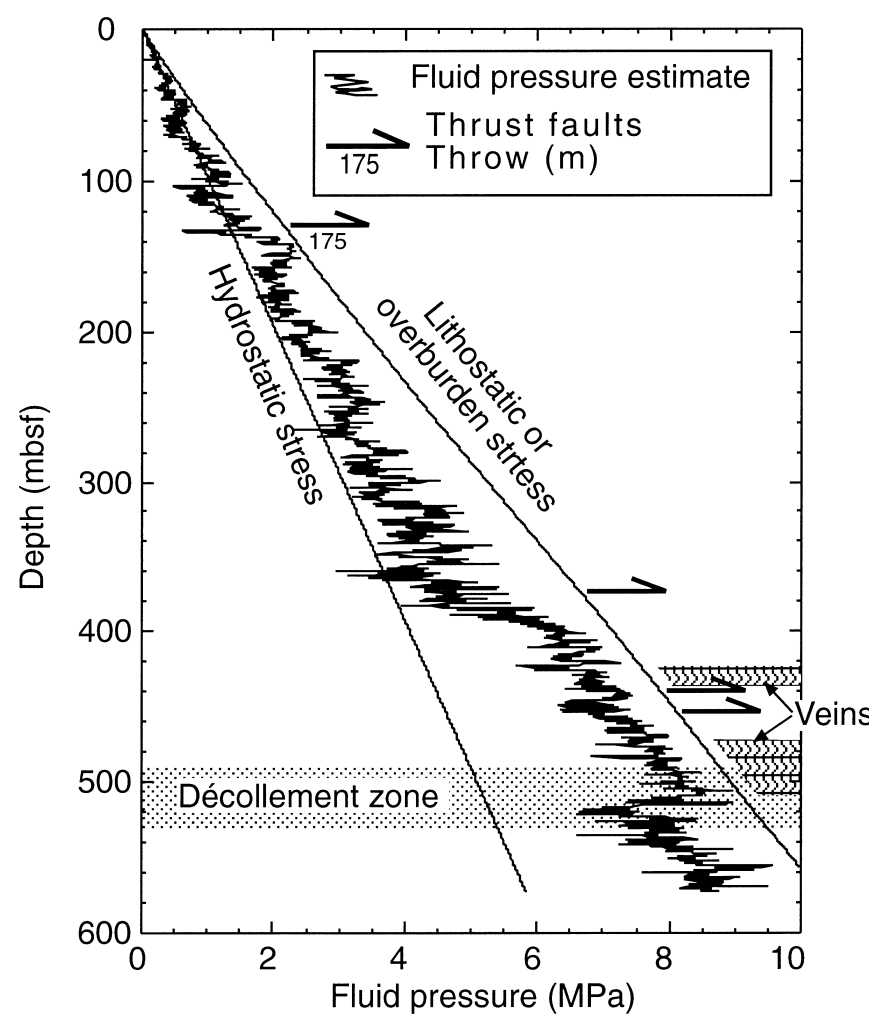

Figure 10. Estimated fluid pressure (corrected) from Site 948.

\section{CONCLUSIONS}

1. Void ratio-effective stress relationships from consolidation tests allow estimation of fluid pressures from physical property data acquired both by LWD and individual sample measurements at the surface.

2. In the accretionary prism, fluid pressure estimates using the void ratio-effective stress relationships require correction for the effects of lateral stress.

3. High, near-lithostatic, fluid pressures characterize the décollement and proto-décollement everywhere. Thrust faults are commonly associated with high fluid pressures. With one exception, mud- and carbonate-filled veins (hydrofractures) occur in zones of high fluid pressures. Smectite-rich clays and claystones characterize the overpressured sections and concentrate the deformation. Deformation and high fluid pressures are probably localized in the clay-rich sections because of their inherent low strength and low permeability.

4. Intervals of highest head (fluid pressure minus hydrostatic pressure) in the décollement (Site 948) and proto-décollement zone (Site 672) correlate with pore-water geochemical anomalies. Because the fluids are not locally derived, the high fluid pressure here must be caused or more probably maintained by external fluid flux.

\section{ACKNOWLEDGMENTS}

Support for this research was provided by USSSP Grant 156$20859 \mathrm{~b}$ to Moore and USSSP Grant 156-20861b to Tobin. Moore was also supported by NSF Grant OCE 9116350 . We appreciate the many contributions of our shipboard colleagues to this study, especially those of Warner Brückmann, Gretchen Zwart, Pierre Henry, Andy Fisher, and Greg Moore. Kevin Brown, Brian McAdoo, Phil Teas, and Gretchen Zwart provided helpful reviews of the manu- script. Jean Bahr, as a supportive editor, substantially improved the manuscript through clarification of the assumptions and techniques used to make the corrections in fluid pressures.

\section{REFERENCES}

Behrmann, J.H., 1991. Conditions for hydrofracture and the fluid permeability of accretionary wedges. Earth Planet. Sci. Lett., 107:550-558.

Biju-Duval, B., Moore, J.C., et al., 1984. Init. Repts. DSDP, 78A: Washington (U. S. Govt. Printing Office).

Blum, P., 1994. Index Properties. In Vers. 155, ODP Shipboard Laboratory Manual: College Station, TX (Ocean Drilling Program).

Brown K., and Ransom, B., 1996. Porosity corrections for smectite-rich sediments: Impact on studies of compaction, fluid generation and tectonic history. Geology, 24:843-846.

Brown, K.M., and Behrmann J., 1990. Genesis and evolution of small-scale structures in the toe of the Barbados Ridge accretionary wedge. In Moore, J.C., Mascle, A., et al., Proc. ODP, Sci. Results, 110: College Station, TX (Ocean Drilling Program), 229-244.

Casagrande, A., 1936. The determination of pre-consolidation load and its practical significance. In Casagrande, A., Rutledge, P.C., and Watson, J.D. (Eds.), Proc. 1st Int. Conf. Soil Mech., Am. Soc. Civ. Eng., 3:60-64.

Davis, D., Suppe, J., and Dahlen, F.A., 1983. Mechanics of fold-and-thrust belts and accretionary wedge. J. Geophys. Res., 88:1153-1172.

Davis, D.M., 1984. The compressive mechanics of accretionary wedges applied to the Leg 78A study area near Barbados. In Biju-Duval, B., Moore, J.C., et al., Init. Repts. DSDP, 78A: Washington (U.S. Govt. Printing Office), 569-579.

Fertl, W.H., 1976. Abnormal formation pressures: Amsterdam (Elsevier).

Gieskes, J.M., Vrolijk, P., and Blanc G., 1990. Hydrogeochemistry of the northern Barbados accretionary complex transect: Ocean Drilling Program Leg 110. J. Geophys. Res., 95:8809-8818.

Han, M.W., and Suess, E., 1989. Subduction-induced pore fluid venting and the formation of authigenic carbonates along the Cascadia continental margin: Implications for the global Ca-cycle. Palaeogeog. Palaeoclimatol. Palaeoecol., 71:97-118.

Hottman, C.E., Smith, J.H., and Purcell, W.R., 1979. Relationships among Earth stresses, pore pressure, and drilling problems, offshore Gulf of Alaska. J. Pet. Technol., 31:1477-1484.

Hubbert, M.K., and Rubey, W.W., 1959. Role of fluid pressure in the mechanics of overthrust faulting, I: Mechanics of fluid-filled porous solids and its application to overthrust faulting. Geol. Soc. Am. Bull., 70:115-166.

Karig, D.E., and Hou, G., 1992, High-stress consolidation experiments and their geologic implications. J. Geophys. Res., 97: 289-300.

Lallemant, S.J., Byrne, T., Maltman, A., Karig, D., and Henry, P., 1993. Stress tensors at the toe of the Nankai accretionary prism: An application of inverse methods to slickenlined faults. In Hill, I.A., Taira, A., Firth, J.V., et al., Proc. ODP, Sci. Results, 131: College Station, TX (Ocean Drilling Program), 103-122.

Mascle, A., Moore, J.C., et al., 1988. Proc. ODP, Init. Repts. (Pt. A), 110: College Station, TX (Ocean Drilling Program).

Mitchell, J.K., 1976. Fundamentals of soil behavior: New York, (John Wiley).

Moore, J.C., Shipley, T., Goldberg, D., Ogawa, Y., et al., 1995. Abnormal fluid pressures and fault-zone dilation in the Barbados accretionary prism: evidence from logging while drilling. Geology, 23:605-608.

Moore, J.C., and Vrolijk, P., 1992. Fluids in accretionary prisms. Rev. Geophys., 30:113-135.

Moran, K., Brückmann, W., Feeser, V., and Campanella, R.G., 1993. In situ stress conditions at Nankai Trough, Site 808. In Hill, I.A., Taira, A., Firth, J.V., et al., Proc. ODP, Sci. Results, 131: College Station, TX (Ocean Drilling Program), 283-291.

Moran, K., and Christian, H.A., 1990. Strength and deformation behavior of sediment from the Lesser Antilles forearc accretionary prism. In Moore, J.C., Mascle, A. et al., Proc. ODP, Sci. Results, 110: College Station, TX (Ocean Drilling Program), 279-288.

Schoonmaker Tribble, J., 1990. Clay diagenesis in the Barbados accretionary complex: Potential impact on hydrology and subduction dynamics. In Moore, J.C., Mascle, A., et al., Proc. ODP, Sci. Results, 110: College Station, TX (Ocean Drilling Program), 97-110.

Serra, O., 1986. Fundamentals of well log interpretation (Vol. 2): The interpretation of logging data. Dev. Pet. Sci., 15B. 
Sherwood, K.W., 1987. Abnormal Formation Pressure. In Turner, R.F. (Ed.), Geological and operational summary, Kodiak Shelf stratigraphic test wells, western Gulf of Alaska. U.S. Department of Interior, Minerals Management Service, OCS Report MMS 87-0109, 229-252.

Shipboard Scientific Party, 1988a. Site 671. In Mascle, A., Moore, J.C., et al., Proc. ODP, Init. Repts., 110: College Station, TX (Ocean Drilling Program), 67-204.

Shipboard Scientific Party, 1988b. Site 672. In Mascle, A., Moore, J.C., et al., Proc. ODP, Init. Repts., 110: College Station, TX (Ocean Drilling Program), 205-310.

Shipboard Scientific Party, 1995a. Explanatory Notes. In Shipley, T.H., Ogawa, Y., and Blum, P., et al., Proc. ODP, Init. Repts., 156: College Station, TX (Ocean Drilling Program), 39-68.

Shipboard Scientific Party, 1995b. Site 948. In Shipley, T.H., Ogawa, Y., and Blum, P., et al., Proc. ODP, Init. Repts., 156: College Station, TX (Ocean Drilling Program), 87-192.

Shipley, T.H., Ogawa, Y., Blum, P., et al., 1995. Proc. ODP, Init. Repts., 156: College Station, TX (Ocean Drilling Program).
Speed, R., Westbrook, G., Mascle, A., Biju-duval, B., Ladd, J., Saunders, J., Stein, S., Schoonmaker, J., and Moore, J., 1984. Lesser Antilles Arc and adjacent terranes. Ocean Margin Drilling Program, Regional Atlas Series: Atlas 10, Woods Hole, MA (Mar. Sci. Int).

Taylor, E., and Leonard, J., 1990. Sediment consolidation and permeability at the Barbados forearc. In Moore, J.C., Mascle, A., et al., Proc. ODP, Sci. Results, 110: College Station, TX (Ocean Drilling Program), 289-308.

Terzaghi, K., and Peck R.B., 1948. Soil mechanics in engineering practice: New York (Wiley).

Twiss, R.J., and Moores, E.M., 1992. Structural geology: New York (Freeman).

von Huene, R., and Lee, H.J., 1983. The possible significance of pore fluid pressure in subduction zones. In Watkins, J.S., and Drake, C.L. (Eds.), Studies in Continental Margin Geology. APG Mem., 34:781-791.

Date of initial receipt: 5 February 1996

Date of acceptance: 3 October 1996

Ms 156SR-030 